\title{
Consumer Protection of Unauthorized Cosmetic Distribution in Indonesia's E-Commerce
}

\author{
Muthia Sakti ${ }^{1}$, Dinda Dinanti² \\ ${ }^{1}$ Faculty of Law UPN Veteran Jakarta \\ muthiasakti@upnvj.ac.id \\ 2 Faculty of Law UPN Veteran Jakarta \\ dindadinanti@upnvj.ac.id
}

\begin{abstract}
Introduction to the Problem: Technological advances in the field of pharmacy or medicine, especially in the field of cosmetics today, have provided many alternatives for consumers, especially women, to meet their needs. The presence of various cosmetic products does provide hope for women to look more beautiful and attractive. But often, many cosmetics products have no active ingredients mentioned. Motivated by big profits, the manufacturers do not register their products for further assessment. When it comes to the market, the products are actually without standard authorization, or in the other cases using false or fictitious marketing authorization numbers. One form of protection to the consumer is the certainty of information contained in cosmetic packaging itself. The distribution of cosmetics without marketing authorization is also commonly found in applications or online stores. Still, on the one hand, it makes it easier for the public to conduct business transactions. However, compared with the easiness the online stores offered, when the products are still unauthorized, it will harm its users.

Purpose/Objective Study: This research discusses consumer protection for the circulation of cosmetics without marketing authorization in Indonesia through ecommerce.

Findings: This research shows that the Indonesian government protects consumers against the circulation of cosmetics without marketing authorization through the rules and laws. However, on the other aspect, those rules or regulations have no practical impact on society in this digital era. So, Indonesia should concern more to online activity where unauthorized marketing products are being marketed.
\end{abstract}

Paper Type: General Review

Keyword: Consumer; Cosmetics; E-Commerce

\section{Introduction}

Globalization and free trade supported by the advances of telecommunications and information technology have expanded the space for the transaction flows of goods and services across national borders so that the marketed items or services offered are varied, both in domestic and foreign production (Chen, 2017; Sutedi, 2008). Thus, the advancements of so-called information and communication technologies (ICTs) 


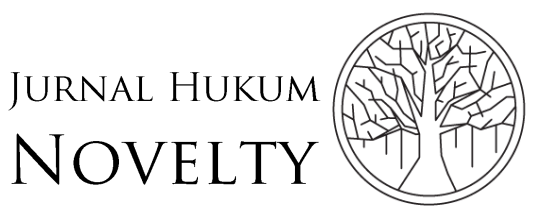

Volume 11, Issue 01, 2020, pp. 31-38
P-ISSN: $1412-6834$

E-ISSN: 2550-0090

have forced new e-commerce improvement. The most noticeable increase in ecommerce is linked to the emerging of social networking sites (SNSs). The variety of social media today has attracted people to go online. By doing so, they could promote, advertise, comment, and rate any products marketed in the online stores (Hajli, 2015; Liang \& Turban, 2011; Zeng, Huang, \& Dou, 2009).

One of the products that are going online is cosmetics. The seducing reviews on particular cosmetic products have influenced people, especially women, to beautify themself more (Syawaluddin, Joni, \& Erwin, 2019). It is because the online world gives more choices and alternatives to certain cosmetic products. Thus, the spreading of products and easiness access are benefitting consumers because it meets their needs. They are free to choose any cosmetic product they want. However, this freedom has Gemini nature; one side is right, and another is the opposite (Featherman \& Hajli, 2016). So, in e-commerce, many consumers are fooled because of the false product. In this condition, they need to be protected when it comes to the dispute between business actors and consumers.

National Agency of Drug and Food Control of Indonesia (hereinafter written as BPOM) in its 2018 annual report stated that based on the commodity, the most violation is a deviation of food standards by $27.30 \%$ ( 80 cases). Meanwhile, the second standard deviation is cosmetic products by $25.56 \%$ (75 cases) and followed by traditional drugs by $20.82 \%$ (61 cases). Most of these violations are due to the products without marketing authorization. The results of BPOM supervision of the Republic of Indonesia from 2015-2018 found that unregistered cosmetics tended to increase, namely: 45 types (2015), 65 types (2016), 88 types (2017), and 178 types (2018). In the event of National Joint Operation, which involved any related sectors (National Health Agency, National Trade Agency, Indonesian Police, and others), BPOM has investigated 189 marketing means. Out of this figure, 93.12\% of these means are illegal. The percentage consists of 12 production factories, 18 distributors, 17 pharmacies, two barbershops or beauty services, 84 stores, 15 drug stores, 14 houses, three warehouses, and 11 other means like online shops or pharmacy warehouses. From this operation, the highest figure of standard violation is unauthorized cosmetics products by 67 marketing cases or $35.45 \%$. On the side of the product, $2,301,392$ pieces of unlicensed cosmetic products or hazardous cosmetic ingredients have been destroyed. It all worth 40,699,804,200 Rupiahs (BPOM, 2018).

The cases mentioned above inevitably violate the consumer's right that may lead to physical damage caused by hazardous cosmetic ingredients. It does not only infringe on the consumer's rights but also deviates the Indonesian Health Act No. 36 of 2009. Thus the assessment of cosmetic products is vital to give an advantage between two parties, which are business actors and consumers. So, the weak position of the consumer is supposed to be protected. However, the protection effort should be balanced between consumers and business actors (Miru \& Yodo, 2004; Rahmayani, 2018). The existence of consumers as weak parties is also reflected in UN General 
Assembly Resolution No. A/RES/39/248 Year 1985, concerning Guidelines for Consumer Protection. Therefore, consumers also need universal legal protection. Judged by the weak position of consumers, the consumer protection topic is always an actual discussion in many aspects (Pane, 2007). Accordingly, this paper is trying to discuss a specific issue of consumer protection that is unauthorized cosmetic products within Indonesia's e-commerce.

\section{Results and Discussion}

Consumer protection laws related to online buying and selling transactions are no different from the laws that apply in direct buying and selling transactions. The difference is only in the use of internet facilities or other telecommunications facilities. However, it is challenging to handle fraud cases in online trading. It is because that the cyber nature of transactions electronically enables everyone, both sellers and buyers, to disguise or falsify identity in every transaction or sale and purchase agreement (Ilham, 2015). The open-access of the online world also causes cyber thievery by stole sensitive information from credit cards and other payment tools (Carta, Fenu, Reforgiato Recupero, \& Saia, 2019; Kanyaru \& Kyalo, 2015). Another aspect is that sometimes seller manipulate their reputation and do a false review for their products to boost their selling (Cai, Tang, Filos-Ratsikas, \& Zhang, 2018). Without exception, one of these challenges also occurred in the online cosmetics market, in which many violation cases lead to consumer loss.

Literary, the word cosmetics came from the Greek word "Kosm tikos." It means having the power to arrange, skilled in decoration, and giving order and harmony (Graham, 2000; Halla et al., 2018). It then has been defined in many laws or regulations to generate standardization of clean cosmetics. In Indonesia, according to BPOM Decree No. HK.00.05.4.1745, cosmetics are materials used on the external human body (hair, nails, lips, or external genital organs), teeth, or oral mucous. While the Indonesian Health Ministry, based on its regulation on Production and Distribution of Cosmetics and Medical Devices No. 220/Men.Kes/Per/IX/76 defines cosmetics as the substance or its mixture to be rubbed, attached, poured, sprinkled, or sprayed on, inserted into, used on the body or its parts for cleaning it, maintaining it, getting more attractive, and changing its appearance.

Indonesian people, mostly like other people in the world, use cosmetics every day to enhance their physical appearance. Types of cosmetics that are commonly used include powder, lipstick, blush, and so forth. In deciding to buy cosmetics, the public as consumers will certainly pay attention to several aspects, including quality and price. The development of social media also influenced consumers before buying a cosmetic product (Hajli \& Sims, 2015; Zhao et al., 2016). Typically, consumers do research or survey the data about the quality of a product through an online search engine like Google, or visually watch the review content on YouTube or surfing into social media like Instagram and Facebook. Many people who do a review of a particular product are commonly called an influencer or YouTubers. The better 


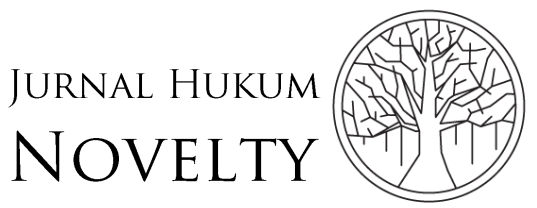

Volume 11, Issue 01, 2020, pp. 31-38
P-ISSN: $1412-6834$

E-ISSN: 2550-0090

reviews, the higher the level of consumer demand for such products (Ferrinadewi, 2005).

Currently, cosmetics circulation is rapidly growing in South Korea (Lee, Sung, Phau, \& Lim, 2019). It leads to the assumption that cosmetic products originating from Korea contain high-quality ingredients and so its quality for Asian skin. The assumption referred to the various reviews on the products that spread useful information. The development of reviews about cosmetic products led to an increase in demand for cosmetic products. Unfortunately, consumer confidence regarding the quality of a product is seen through other people's reviews, despite consumer concerns over the composition contained in the cosmetic product. When consumers have seen discussions on social media or electronic media, it will emerge a sense of curiosity about the particular cosmetic product. Furthermore, consumers will try to get and try to apply cosmetic products for themselves without paying attention to the composition contained in the product.

Getting cosmetic products after researched them is the issue. The fast and reliable means to purchase the products is through online shopping. There are various and famous online shopping media used by Indonesian people, such as Lazada, Tokopedia, or Bukalapak. However, online stores are suspiciously fooling consumers for their unrigorously. Although it could happen in every online media, be it a famous one or unofficial (Arlina, 2018). Some of the online transaction problems of cosmetics products can be analyzed from the opinion of Abdul Halim Barkatullah (2007):

1. Consumers tend not to see the goods directly to be ordered. So it is like blind purchasing, ordering without positively sure the physical products.

2. Unclear product information.

3. The legal subject status of the producer is unknown.

4. There are no guarantees of transaction security and privacy, as well as an explanation of the risks associated with the system used, especially in the case of electronic payments both by credit card and electronic cash.

5. The amount has been paid in advance, while items may not be received or will be received at a later date. What makes it worse is, there is only a guarantee of delivery, not a guarantee of receiving goods.

6. Borderless transactions are raising questions about the legal jurisdiction of which countries should be enforced.

Authorization is the consent form for the registration of medicinal products, traditional medicines, cosmetics, food supplements, and food issued by BPOM. By this consent form, the product can be lawfully marketed in the Indonesian territory. It is known that one of the purposes of the enactment of marketing authorization or product registration approval in Indonesia is to protect the public from the circulation of products that do not meet safety, quality, and usefulness requirements. 
The legal basis for registration of cosmetics in Indonesia has undergone many revisions adapting to the evolving information technology. The first statutory regulation governing marketing authorization is the Indonesian Health Ministry Regulation No. 326/Menkes/Per/XII/1976 on Obligatory Registration of Cosmetics and Medical Devices. It then revoked and declared invalid by the issuance of Regulation No. 140/Menkes/Per/III/1991 on the same concern. In 2004, the Health Ministry regulated Safeguarding Medical Devices and Household Health Supplies Medical Devices No. 1184/Menkes/Per/X/2004. This regulation revokes four regulations at the same time, which are Regulation No. 220/Menkes/Per/IX/76, Regulation No. 236/Menkes/Per/X/1977, Regulation No. 140/Menkes/Per/III/1991, and Regulation No. 142/Menkes/Per/III/1991.

Today, the Indonesian legal umbrella for consumers of cosmetic products is Act No. 8 of 1999 concerning Consumer Protection. It also supported by the Head of BPOM Regulation No. HK.00.05.42.2995 of 2008 on Supervision of Cosmetics Imports, Regulation of the Head of BPOM No. HK.00.05.1.23.3516 of 2009, and Head of BPOM Decree No. HK.00.05.4.1745 of 2003 concerning Cosmetics.

The circulation of cosmetic products in Indonesia must go through a long process and stages. The method of examining the ingredients of a product will be carried out by the Indonesian Food Drug Supervisory Agency. After going through the inspection process, BPOM will issue a marketing authorization for a product. It aims to guarantee that the products contain safe ingredients for the skin and body. Consumer Protection Law in Indonesia has a legal basis that has been established by the government. Based on the Head of the Republic of Indonesia Drug and Food Regulatory Agency Regulation Number HK.03.1.23.12.11.10052 of 2011 concerning Cosmetics Production and Distribution Control, there are three common ways which often used by parties who are authorized to protect their consumer rights, namely:

1. Revocation of Cosmetic Distribution Permits and Cosmetics Industry Permits.

2. Withdrawal of the circulation of hazardous cosmetic products.

3. Sanctions and compensation.

But in practice, law enforcement in Indonesia related to the circulation of illegal cosmetics is less effective. One example is the decision of the Mojokerto District Court to sentence five months imprisonment for illicit cosmetics distribution. The Panel of Judges found the defendant guilty and was proven to violate Article 197 and 196 of Act No. 36 of 2009 on Health. Thus, this matter has not adequately protected consumers because the punishment given by judges to business actors does not provide a deterrent effect and is less compared to the impact of community when using cosmetics without marketing authorization.

\section{Conclusion}

Consumer protection for the circulation of cosmetics without marketing permission in e-commerce is based on the Consumer Protection Act. The law states that each 


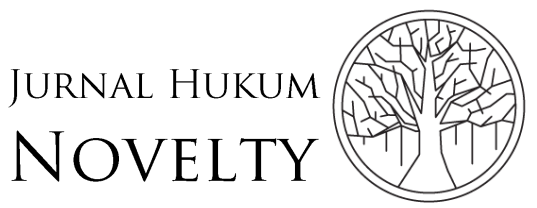

Volume 11, Issue 01, 2020, pp. 31-38
P-ISSN: $1412-6834$

E-ISSN: 2550-0090

consumer must obtain precise information about a product that will be consumed or used. The certainty of data can be known through the packaging of cosmetic products. The report includes information about the marketing authorization number, product composition, expiration date, how to use the product for product side effects.

The recent development of technology makes it easier for people to be able to get cosmetic products. So that more and more business activities are selling cosmetics through online media. Disadvantages of online transactions include that consumers cannot be sure directly about the condition of the product when purchasing. So here it takes good faith from business people to be able to provide correct information about the products. Therefore, the Consumer Protection Act provides a solution for people who feel the disadvantage, which is reporting the actions of adverse business actors. However, the existence of regulations on consumer protection is still not enough to protect consumers; this is evidenced by the still rampant business players who trade cosmetics without marketing authorization. In this case, it urgently needs an increase in the supervision of cosmetics distribution conducted by the competent authority.

\section{References}

Arlina, S. (2018). Perlindungan konsumen dalam transaksi jual beli online produk kosmetik (pemutih wajah) yang mengandung zat berbahaya berdasarkan Undang-Undang Nomor 8 Tahun 1999. UIR Law Review, 2(1), 317. https://doi.org/10.25299/uirlrev.2018.2.01.991

Barkatullah, A. H. (2007). Urgensi perlindungan hak-hak konsumen dalam transaksi di e-commerce. Jurnal Hukum IUS QUIA IUSTUM, 14(2), 247-270. https://doi.org/10.20885/iustum.vol14.iss2.art8

BPOM. (2018). Laporan tahunan BPOM tahun 2017. In Badan POM. Retrieved from https://www.pom.go.id/new/admin/dat/20191212/LAPTAH-BPOM-2018.pdf

Cai, Q., Tang, P., Filos-Ratsikas, A., \& Zhang, Y. (2018). Reinforcement mechanism design for fraudulent behaviour in e-commerce. 32nd AAAI Conference on Artificial Intelligence, AAAI 2018, 321171, 957-964. Retrieved from https://www.aaai.org/ocs/index.php/AAAI/AAAI18/paper/viewPaper/16650

Carta, S., Fenu, G., Reforgiato Recupero, D., \& Saia, R. (2019). Fraud detection for ecommerce transactions by employing a prudential Multiple Consensus model. Journal of Information Security and Applications, 46, 13-22. https://doi.org/10.1016/j.jisa.2019.02.007

Chen, L. (2017). Developing Asia in the era of cross-border e-commerce. In Economic Research Institute for ASEAN and East Asia (ERIA) (No. ERIA-DP-2017-11). Retrieved from https://think-asia.org/bitstream/handle/11540/7663/ERIADP-2017-11.pdf?sequence=1

Featherman, M. S., \& Hajli, N. (2016). Self-service technologies and e-services risks in social commerce era. Journal of Business Ethics, 139(2), 251-269. https://doi.org/10.1007/s10551-015-2614-4

Ferrinadewi, E. (2005). Atribut produk yang dipertimbangkan dalam pembelian 
kosmetik dan pengaruhnya pada kepuasan konsumen di Surabaya. Jurnal Manajemen Dan Wirausaha, 7(2), 139-151. https://doi.org/10.9744/jmk.7.2.pp.139-151

Graham, J. A. (2000). The psychology of fragrance and aromatherapy. In H. Butler (Ed.), Poucher's Perfumes, Cosmetics and Soaps (10th ed., pp. 749-767). https://doi.org/10.1007/978-94-017-2734-1_25

Hajli, N. (2015). Social commerce constructs and consumer's intention to buy. International Journal of Information Management, 35(2), 183-191. https://doi.org/10.1016/j.ijinfomgt.2014.12.005

Hajli, N., \& Sims, J. (2015). Social commerce: The transfer of power from sellers to buyers. Technological Forecasting and Social Change, 94, 350-358. https://doi.org/10.1016/j.techfore.2015.01.012

Halla, N., Fernandes, I. P., Heleno, S. A., Costa, P., Boucherit-Otmani, Z., Boucherit, K., ... Barreiro, M. F. (2018). Cosmetics preservation: A review on present strategies. Molecules, 23(7), 1-41. https://doi.org/10.3390/molecules23071571

Ilham, R. A. (2015). Perlindungan hukum terhadap konsumen atas penjualan obatobatan ilegal secara online. Jurnal Hukum, 10-17. https://doi.org/10.1145/3132847.3132886

Kanyaru, P. M., \& Kyalo, J. K. (2015). Factors affecting the online transactions in the developing countries: A case of e-commerce businesses in Nairobi country, Kenya. Journal of Educational Policy and Entrepreneurial Research (JEPER), 2(3), 1-7. Retrieved from http://www.jeper.org/index.php/JEPER/article/viewFile/91/103

Lee, S., Sung, B., Phau, I., \& Lim, A. (2019). Communicating authenticity in packaging of Korean cosmetics. Journal of Retailing and Consumer Services, 48, 202-214. https://doi.org/10.1016/j.jretconser.2019.02.011

Liang, T.-P., \& Turban, E. (2011). Introduction to the special issue social commerce: A research framework for social commerce. International Journal of Electronic Commerce, 16(2), 5-14. https://doi.org/10.2753/JEC1086-4415160201

Miru, A., \& Yodo, S. (2004). Hukum perlindungan konsumen. Jakarta: Raja Grafindo Persada.

Pane, E. (2007). Perlindungan konsumen dalam perspektif undang-undang perlindungan konsumen dan hukum Islam. Pranata Hukum, 2(1), 60-78. Retrieved from https://media.neliti.com/media/publications/26675-IDperlindungan-konsumen-dalam-perspektif-undang-undang-perlindungankonsumen-dan-h.pdf

Rahmayani, N. (2018). Tinjauan hukum perlindungan konsumen terkait pengawasan perusahaan berbasis financial technology di Indonesia. Pagaruyuang Law Journal, 2(1), 24-41. Retrieved from https://jurnal.umsb.ac.id/index.php/pagaruyuang/article/view/887/798

Sutedi, A. (2008). Tanggungjawab produk dalam hukum perlindungan konsumen. Bogor: Ghalia Indonesia.

Syawaluddin, S., Joni, J., \& Erwin, E. (2019). Influence of social media advertising, e- 
marketing and product quality on the process of purchasing nature cosmetics. International Journal of Research in Business and Social Science (2147- 4478), 8(5), 316-321. https://doi.org/10.20525/ijrbs.v8i5.491

Zeng, F., Huang, L., \& Dou, W. (2009). Social factors in user perceptions and responses to advertising in online social networking communities. Journal of Interactive Advertising, 10(1), 1-13. https://doi.org/10.1080/15252019.2009.10722159

Zhao, W. X., Li, S., He, Y., Chang, E. Y., Wen, J.-R., \& Li, X. (2016). Connecting social media to e-commerce: Cold-start product recommendation using Microblogging Information. IEEE Transactions on Knowledge and Data Engineering, 28(5), 1147-1159. https://doi.org/10.1109/TKDE.2015.2508816 